\title{
Comparative hematological analysis of Morada Nova and Santa Inês ewes in all reproductive stages ${ }^{1}$
}

\author{
Leílson R. Bezerra², Wagner D.C. Oliveira², Tairon P.D. Silva ${ }^{3 *}$, Jacira N.C. Torreão ${ }^{4}$, \\ Carlo A.T. Marques ${ }^{4}$, Marcos J. Araújo ${ }^{2}$ and Ronaldo L. Oliveira ${ }^{5}$
}

\begin{abstract}
Bezerra L.R., Oliveira W.D.C., Silva T.P.D., Torreão J.N.C., Marques C.A.T., Araújo M.J. \& Oliveira R.L. 2017. Comparative hematological analysis of Morada Nova and Santa Inês ewes in all reproductive stages. Pesquisa Veterinária Brasileira 37(4):408414. Departamento de Zootecnia, Universidade Federal do Piauí, Bom Jesus, PI 64 900-000, Brazil. E-mail: tairon.mvet@gmail.com

Hematologic analysis provides reliable information on the health status of animals. It is an important variable in the assessment of adaptive and productive capacity of breeds under unfavorable environmental conditions. It is an assessment that combined with other genetic and environmental factors and management can become useful for the future sustainability of mainstream agriculture in a hot environment. Adaptive capacity is affected by some factors such as breed, pregnancy and lactation. Therefore, hematological profile is an important indicator of animal health and production. The objective of this study was to perform the comparative hematological analysis of Santa Inês and Morada Nova breeds (native ewes from Brazil) in all different reproductive stages. Twenty Santa Ines and 20 Morada Nova sheep distributed in a completely randomized design in a split-plot arrangement over time were used. To obtain blood counts, blood samples were collected by jugular venipuncture every 14 days, always in the morning, before the animals were released into the pasture. The Morada Nova breed had higher hemoglobin and total leukocyte count than Santa Inês breed. Regarding the influence of pregnancy and puerperium on the eritrogram, there was an increment in red blood cell, hemoglobin and packed cell volume of both breeds in middle pregnancy. However, had a reduction in late pregnancy. There were a reestablishment of the blood cell counts during the puerperium period. It was verified an increase on neutrophil: lymphocyte ratio indicated that ewes in the late pregnancy, postpartum and puerperium were under stress conditions compared to others reproductive stages. The total plasma proteins also increased during this period to compensate for the high nutritional requirements of the fetus, and these levels remained high until the end of the puerperal phase, when the lambs were weaned. The pregnancy and puerperium influenced all erythrocyte indices and changed the total leukocyte count.
\end{abstract}

INDEX TERMS: Hematological analysis, Morada Nova ewes, Santa Inês ewes, reproductive stages, hemoglobin, indigenous sheep, leukocyte count, parturition.

\footnotetext{
${ }^{1}$ Received on June 10, 2015.

Accepted for publication on September 5, 2016.

${ }^{2}$ Departamento de Zootecnia, Universidade Federal do Piauí (UFPI), Bom Jesus, PI 64900-000, Brazil.

${ }^{3}$ Laboratório de Nutrição Animal, Centro de Energia Nuclear na Agricultura, Universidade de São Paulo (USP), Piracicaba, SP 13425-970, Brazil. *Corresponding author: tairon.mvet@gmail.com

${ }^{4}$ Universidade Federal de Sergipe, Campus Sertão, Rodovia Engenheiro Jorge Neto Km 3, Silos Nossa Senhora da Glória, SE 49680-000, Brazil.

${ }^{5}$ Departamento de Zootecnia, Escola de Medicina Veterinária e Zootecnia, Universidade Federal da Bahia (FBA), Av. Ademar de Barros 500, Ondina, Salvador, BA 40170-110, Brazil.
}

RESUMO-- [Análise hematológica comparativa de ovelhas Morada Nova e Santa Inês em todos os estágios reprodutivos.] A análise hematológica fornece informação confiável sobre a saúde dos animais. É uma variável importante na avaliação da capacidade adaptativa e produtiva das raças sob condições ambientais desfavoráveis. É uma avaliação que aliada a outros fatores genéticos, ambientais e de manejo pode se tornar cada vez mais útil para a sustentabilidade futura da agricultura convencional em um ambiente quente. A capacidade adaptativa é afetada por alguns fatores como raça, gestação e lactação. Portanto, o 
perfil hematológico é um indicador importante da saúde e produção animal. 0 objetivo deste estudo foi realizar a análise hematológica comparativa de ovelhas Morada Nova e Santa Inês (ovelhas nativas do Brasil) em todos os estágios reprodutivos. Foram utilizadas 20 ovelhas Santa Inês e 20 Morada Nova distribuídas em um delineamento inteiramente casualizado, em parcelas subdivididas e medidas repetidas no tempo. Para a análise do sangue, foram coletadas amostras por venopunção jugular a cada 14 dias, sempre colhidas pela manhã, antes que os animais fossem soltos no pasto. A raça Morada Nova apresentou maior teor de hemoglobina e contagem total de leucócitos que a raça Santa Inês. Em relação à influência da gestação e do puerpério sobre o eritrograma, observou-se que houve um incremento dos valores da contagem dos eritrócitos, hematócrito e hemoglobina até o terço médio da gestação, reduzindo no final da gestação e restabelecendo novamente no período puerperal. Foi verificado um aumento na relação neutrófilo/linfócito indicando que ovelhas no final da gestação, no pós-parto e puerpério estavam sob condição de estresse comparado com os outros estágios reprodutivos. As proteínas plasmáticas totais também aumentaram durante o período gestacional para compensar os altos requisitos nutricionais do feto, e estes níveis permaneceram elevados até ao final da fase de puerpério quando os cordeiros foram desmamados. A gestação e o puerpério influenciaram todos os índices eritrocitários com alteração da contagem total de leucócitos.

TERMOS DE INDEXAÇÃO: Análise hematológica comparativa, ovelhas, Morada Nova, Santa Inês, estágios reprodutivos, leucócitos, hemoglobina, ovinos nativos, parto.

\section{INTRODUCTION}

The sheep industry exists in different climates and for different purposes around the world. Sheep are raised in a wide range of climates, from arid to cold regions, for the production of meat, wool, skin or milk. The success of the production cycle of a sheep is determined by its production level, the postpartum recovery reproductive function and absence of pathology. Undoubtedly, the achievement of these objectives depends largely on the state of animal in its early days postpartum. So much so, that the level of production, the level of intake and blood parameters (hematological e biochemical) in the first week postpartum are good indicators of return to reproductive activity (Bezerra et al. 2013) However, regardless of the region in which animals are handled, the transition period consists of two phases, the first being formed by last three weeks before calving and the second by the first three weeks postpartum. This period is marked by changes, some of these are related to alterations in energy requirements driven by both fetal needs and lactogenesis, endocrine and metabolic and preparing for childbirth and lactation. In this period, hematological and biochemical parameters, are efficient indicative of homeostasis, are used to evaluate nutritional, health and adaptive aspects of sheep breeds (Ali et al. 2010).

According to Yaqub et al. (2013), the nutritional management of pets may affect the recovery of the hematopoie- tic populations during the postpartum period. Therefore, research is needed to identify these nutritional factors and to determine if food supplementation or the use of hematopoietic substances during late pregnancy and postpartum is beneficial for the restoration of blood cells.

Thus, it is evident that additional studies are needed to determine the hemogram reference values for different sheep breeds, and different physiological stages, such as pregnancy and puerperium and feeding conditions, because they are determining in the occurrence of nutritional diseases during the reproductive period. Studies are also needed to evaluate the factors that influence the homeostasis mechanism (Bezerra et al. 2008). Among these factors, those related to pregnancy are important to study, including birth and the postpartum period. These changes are referred to as the "physiologic anemia of pregnancy" and have been described in goats and cattle.

In small ruminants, the most important productive parameter is their efficient reproductive activities. To improve the economy of sheep farms, farmers have to ensure regular lambing. Hence, proper reproductive management of sheep is very crucial from economic perspectives. Our hypothesis was that different reproductive stages could affect hematological profile of Santa Inês and Morada Nova ewes in a semi-arid environment. Accordingly, the purpose of this study was to compare hematological profile of Santa Inês and Morada Nova breeds (native ewes from Brazil) in all different reproductive stages.

\section{MATERIALS AND METHODS}

This study was conducted between October 2011 and June 2012 in the Research Unit in Small Ruminants and Clinical Pathology Laboratory Campus Prof. Cinobelina Elvas Federal University of Piauí. Forty pluriparous sheep, being 20 animals of the Morada Nova breed and 20 of the Santa Ines breed, all of which were artificially inseminated. The protocol involved in the application of intravaginal sponge containing $60 \mathrm{mg}$ of medroxiprogesterone acetate (Progespon ${ }^{\circledR}$ Syntex S.A, Argentina) for 9 days. After sponge removal, beginning of the FSH treatment, 200UI of eCG (Folligon $5000^{\circledR}$, Intervet, Holanda) and $0.1 \mathrm{mg}$ of cloprostenol sodium (Ciosin ${ }^{\circledR}$, Intervet, Holanda) were given intra muscular (IM) to synchronize the follicular wave and stimulate ovulations. On day 30, post-artificial insemination, trans-abdominal ultrasonography (50S Tringa Vet, Pie Medical, Maastricht, The Netherlands; transducer of $3.5 / 5.0 \mathrm{MHz}$ ) was used to detect pregnancy. Prophylactic measures against sheep diseases like sheep pox, peste des petits ruminants, enterotoxaemia, endo and ectoparasitic infestations were carried out as prescribed by the health calendar of the institute to ensure that the animals were in healthy condition throughout the study. On day 60, post-artificial insemination, trans-abdominal ultrasonography (50S Tringa Vet, Pie Medical, Maastricht, The Netherlands; transducer of $3.5 / 5.0 \mathrm{MHz}$ ) was used to detect pregnancy.

This work followed all ethical principles involving animals in research and was approved by the Bioethics Committee of Federal University of Piauí (protocol number CPCE-61/2010).

During the experimental period, the sheep remained in paddocks containing Andropogon gayanus, which was collected in the late afternoon and allocated to individual pens where supplementation consisting of cracked corn (70\%), soybean meal (25\%) and mineral supplement (5\%), based on the dry matter, was ad- 
ded (Table 1). The supplement concentrations were formulated according to the recommendations of the NRC (2007).

Blood samples were collected every 14 days, including 30 days before insemination and from the 30th day of gestation until the 90th day of lactation (at which time the lambs were weaned). Groups were formed according to breed and the stage of pregnancy or lactation (Table 2).

Blood samples were always collected by jugular venipuncture in the morning before the animals were released to pasture, disposable needles $(25 \times 8 \mathrm{~mm} ; 21 \mathrm{G})$ and glass vacutainer tubes containing $0.05 \mathrm{ml}$ of a $10 \%$ aqueous solution of ethylene diamine tetraacetic acid (EDTA) per $5 \mathrm{ml}$ of blood were used. The blood samples were kept in a cooler with ice (temperature between 2 and $8^{\circ} \mathrm{C}$ ) until they were transported to the Clinical Pathology Laboratory (CPCE-UFPI), where the hemogram was performed within 24 hours (Oliveira et al. 2010). The hemogram consisted of the following measurements: global erythrocyte counts, packed cell volume, hemoglobin, absolute blood indices (mean corpuscular volume-MCV, mean corpuscular hemoglobin concentration -MCHC) and total and differential leukocyte counts. The erythrocyte counts were performed using a modified Neubauer chamber and Gower's solution as a diluent. The packed cell volume was determined with the microhematocrit technique, using homogeneous capillary tubes of $75 \mathrm{~mm}$ in length and one millimeter in diameter. After differential leukocyte counts the neutrophil:lymphocyte (N/L) ratios was determined.

The determination of the hemoglobin content in the blood was made by the cyanmethemoglobin method, using Drabkin's solution for the dilutions. The values obtained by counting the red blood cells (RBC) and determining the packed cell volume and hemoglobin content served to establish the absolute values of $\mathrm{RBC}$ indices prior to obtaining specific leukocyte counts. Total leukocyte counts were performed in a modified Neubauer chamber, and blood samples were diluted 1:20 in Turk's solution, according to the recommendations of Viana et al. (2002). Two smears of whole blood were used for the differential leukocyte counts. After drying, the smears were stained using a quick Romanowsky-type dye (Panoptic rapid - Ltda LaborClin ${ }^{\circledR}$, Pinewoods, Paraná, Brazil), according to a standardized technique for animals by Viana et al. (2002). Using a microscope at 1000x magnification, 100 leukocytes were classified in each blood smear according to morphology and staining patterns. The leukocytes were classified as rod neutrophils, core-segmented neutrophils, eosinophils, basophils, lymphocytes or monocytes. The determination of total plasma protein (TPP) was performed by refractometry after the blood was centrifuged in microhematocrit capillary tubes.

The experiment was conducted in a completely randomized design. The effects of reproductive stages (non-pregnant, initial pregnancy, middle pregnancy, late pregnancy, postpartum, puerperium and weaning) and breed (Santa Inês and Morada Nova) were considered. The blood variables were evaluated by split plots. The main plot included the breed and reproductive stages, while the secondary plot involved the harvest periods with repeated measures. The means were compared with the Student-Newman-Keuls test, and significance of an effect was stated when P-value $<0.05$. All statistical analyses were performed with SAS Software version 9.1 (Cary, North Carolina).

\section{RESULTS AND DISCUSSION}

Hematologic analysis provides reliable information on the health status of animals (Cetin et al. 2009). It is not only relevant for diagnosing disorders of the hematologic system but also is important indices of animal health and production (Oladele et al. 2005). Several factors affect cellular and plasma haemodynamics such as breed (Tibbo et al. 2008), pregnancy (Farooq et al. 2011) and lactation (Harewood et al. 2000). The results of this study demonstrated that the total red cell count was influenced only by the reproductive stages $(\mathrm{P}<0.0001)$ and was not affected by breed $(\mathrm{P}>0.4718)$ or interaction between the factors (Table 3$)$.

The interaction between breed and reproductive stages influenced on hemoglobin content $(\mathrm{P}=0.0007)$ and packed

Table 1. Chemical composition of experimental ingredients and concentrate supplement

\begin{tabular}{lcccccc}
\hline Ingredient & \multicolumn{6}{c}{ Chemical composition (\% DM) } \\
\cline { 2 - 7 } & DM & CP & EE & TDN & Ca & P \\
\hline Corn meal & 87.19 & 9.98 & 5.19 & 67.50 & 0.05 & 0.49 \\
Soybean meal & 88.48 & 48.76 & 1.75 & 80.73 & 0.33 & 0.57 \\
Mineral mixture & 97.91 & - & - & - & 18.00 & 13.00 \\
Supplement concentrate & 88.04 & 19.17 & 4.06 & 67.43 & 1.01 & 1.13
\end{tabular}

$\overline{\mathrm{DM}}=$ Dry matter $; \mathrm{PB}=$ Crude protein $; \mathrm{EE}=$ Ether extract $; \mathrm{TDN}=$ Total

Digestible Nutrients; $\mathrm{Ca}=$ Calcium; $\mathrm{P}=$ Phosphorus.

Table 2. Constitution of the experimental groups for the evaluation of the influence of pregnancy and puerperium on the hemogram values of healthy Morada Nova and Santa Inês sheep

\begin{tabular}{ccl}
\hline Group & N & \multicolumn{1}{c}{ Constitution of the experimental groups } \\
\hline I & 40 & $\begin{array}{l}\text { Not pregnant: non-pregnant adult females. } \\
\text { Initial pregnancy: pregnant females with gestational } \\
\text { periods between } 30 \text { and } 60 \text { days. } \\
\text { II }\end{array}$ \\
III & 40 & $\begin{array}{l}\text { Middle pregnancy: pregnant females with gestational } \\
\text { periods between } 60 \text { and } 120 \text { days. }\end{array}$ \\
IV & 40 & $\begin{array}{l}\text { Late pregnancy: pregnant females with over } \\
\text { 120 days of gestation. }\end{array}$ \\
V & 40 & $\begin{array}{l}\text { Postpartum: females up to } 30 \text { days postpartum. } \\
\text { Puerperium: females during puerperium, }\end{array}$ \\
VI & 40 & $\begin{array}{l}\text { 30-60 days postpartum. } \\
\text { Weaning: females with weaned lambs, } \\
\text { over } 60 \text { days postpartum. }\end{array}$ \\
VII & 40 &
\end{tabular}

Table 3. Variance Analyses and $P$-value of erythrocyte and leukocyte parameters of Santa Inês and Morada Nova sheep at different reproductive stages

\begin{tabular}{|c|c|c|c|}
\hline \multirow[t]{2}{*}{ Variables } & \multicolumn{3}{|c|}{ Erythrogram } \\
\hline & Breed & $\begin{array}{c}\text { Stages } \\
\text { reproductive }\end{array}$ & $\begin{array}{c}\text { Breed } \times \text { Stages } \\
\text { reproductive }\end{array}$ \\
\hline Erythrocyte $\left(\mathrm{x} 10^{6} / \mu \mathrm{L}\right)$ & $0.4718^{\mathrm{ns}}$ & $<.0001^{* *}$ & $0.8175^{\mathrm{ns}}$ \\
\hline Hemoglobin (g dL-1) & $<.0001^{* *}$ & $<.0001^{* *}$ & $0.0007^{* *}$ \\
\hline Packed cell volume (\%) & $<.0001^{* *}$ & $0.0356^{*}$ & $0.0008^{* *}$ \\
\hline $\operatorname{MCV}\left(\mu m^{3}\right)$ & $0.2080^{\mathrm{ns}}$ & $<.0001^{* *}$ & $0.2601^{\mathrm{ns}}$ \\
\hline MCHC (\%) & $<.0001^{* *}$ & $<.0001^{* *}$ & $0.3599^{\text {ns }}$ \\
\hline TPP (g dL-1) & $0.2609^{\text {ns }}$ & $<.0001^{* *}$ & $0.2653^{\mathrm{ns}}$ \\
\hline \multicolumn{4}{|l|}{ Leukogram } \\
\hline Leukocytes (cells $\mu^{-1}$ ) & $0.0024^{* *}$ & $0.0243^{*}$ & $0.0006^{* *}$ \\
\hline Neutrophils (cells $\mu \mathrm{l}^{-1}$ ) & $0.4220^{\mathrm{ns}}$ & $<.0001^{* *}$ & $<.0001^{* *}$ \\
\hline Eosinophils (cells $\mu \mathrm{l}^{-1}$ ) & $0.5103^{\mathrm{ns}}$ & $0.0027^{\mathrm{ns}}$ & $0.4517^{\mathrm{ns}}$ \\
\hline Monocytes (cells $\mu^{-1}$ ) & $0.4358^{\mathrm{ns}}$ & $0.1412^{\mathrm{ns}}$ & $0.1091^{\mathrm{ns}}$ \\
\hline Lymphocytes (cells $\mu^{-1}$ ) & $0.0503^{\text {ns }}$ & $0.0481^{*}$ & $0.0010^{* *}$ \\
\hline Basophils (cells $\mu^{-1}$ ) & $0.6655^{\mathrm{ns}}$ & $0.5950^{\mathrm{ns}}$ & $0.4000^{\mathrm{ns}}$ \\
\hline Neutrophils/ Lymphocytes & $0.3250^{\text {ns }}$ & $<.0301^{*}$ & $<.3101^{\mathrm{ns}}$ \\
\hline
\end{tabular}

$\mathrm{MCV}=$ mean corpuscular volume; $\mathrm{MCHC}=$ mean corpuscular hemoglobin concentration; TPP = Total Plasma Protein; ns = not significant, $* *$ significant $(\mathrm{P}<0.01)$, and * significant $(\mathrm{P}<0.05)$ by the Student-Newman-Keuls test. 
cell volume $(\mathrm{P}=0.0008)$. As for the absolute $\mathrm{RBC}$ index, both the MCV and MCHC were influenced by the reproductive stages $(\mathrm{P}<0.0001)$. The TPP was also influenced by the reproductive stages $(\mathrm{P}<0.0001)$.

Blood parameters have been used to globally assess the health status of animals and as indicators of heat stress. Multiple factors including the species, sex, age, physiological state, diseases, time of day, relative humidity, ambient temperature and muscle activity can all influence hematological parameters (Adili \& Melizi 2013, Adili et al. 2013, Bamorovat et al. 2013, Papaioannou et al. 2013, Yaqub et al. 2013, Dias et al. 2010).

Variations in the packed cell volume and hemoglobin levels have been linked to the factor of breed in previous studies (Adili \& Melizi 2013, Adili et al. 2013). The changes in packed cell volume depend on the severity of the heat load imposed on the animal. Thus, animals that suffer from prolonged stress tend to have decreased PCV levels.

According to the comparative hematological analysis, mainly, based on PCV and hemoglobin ((Adili \& Melizi 2013, Adili et al. 2013) the Morada Nova breed presented high adaptive capacity than Santa Inês breed in semi-arid conditions, but still suffers consequences when subjected to stressful conditions. Generally, the haematological profile is an important indicator of the influence of thermal environment changes on the physiological responses of animals. Changes in haematological parameters such as total red blood cells (RBC) count and indices (MCV and MCHC) are of value in determining the adaptation of animals to the environment. Hemoglobin concentration and packed cell volume are also indicative of adaptation to adverse environmental conditions. Indeed, haematological values are used to asses stress and welfare in animals, especially the neutrophil/lymphocyte ratio (Stanger et al. 2005, Minka \&
Ayo 2007, Yaqub et al. 2013). Despite the variation observed, the packed cell volume values were within the normal range (Kramer 2006).

The difference among hemoglobin, packed cell volume level and higher white cell counts (total leukocyte and lymphocyte counts) showed that Morada Nova and Santa Inês Breed presented different adaptive behavior in semi-arid conditions, but with values within the normal range for the specie (Kramer 2006). These result show that more experiment are necessary to determine others factors that affect indirectly and directly the adaptation physiology of these breeds. Mainly, due to the higher importance that the sheep production has for the semi-arid environment. This region (semi-arid) is one of the major agro ecological zones of the tropics. There is, in general, a strong relationship between agro-climatic conditions, population density, cropping systems, and livestock production. Rangelands are the largest land use system on earth. They predominate in semi-arid tropical areas of the world. These pastoral systems are those in which people depend entirely on livestock for their livelihood. Ruminant livestock are critical to the development of sustainable and environmentally sound production systems (Ben Salem 2010).

The total leukocyte count was influenced by the factors of breed $(\mathrm{P}=0.0024)$, animal category $(\mathrm{P}=0.0243)$ and the interaction between race and reproductive stages $(\mathrm{P}=0.0006)$. None of the variables affected the total eosinophils, monocyte or basophil cells counts. Only the animal category influenced the differential neutrophil cells count $(\mathrm{P}<0.0001)$. In addition, the reproductive stages influenced the interaction between class and race $(\mathrm{P}<0.0001)$. The factor reproductive stages $(\mathrm{P}=0.0481)$ also influenced the lymphocyte count.

Changes in the number of leukocytes and the differen-

Table 4. Means, significance and reference values of Santa Inês sheep in all reproductive stages

\begin{tabular}{|c|c|c|c|c|c|c|c|}
\hline \multirow[t]{2}{*}{ Animal Category } & \multicolumn{7}{|c|}{ Erythrogram } \\
\hline & $\begin{array}{l}\text { Erythrocyte } \\
\left(\mathrm{x} 10^{6} / \mu \mathrm{L}\right)\end{array}$ & $\begin{array}{l}\text { Hemoglobin } \\
\qquad\left(\mathrm{g} \mathrm{dL}^{-1}\right)\end{array}$ & $\begin{array}{l}\text { Packed cell } \\
\text { volume (\%) }\end{array}$ & $\begin{array}{c}\mathrm{MCV} \\
\left(\mu \mathrm{m}^{3}\right)\end{array}$ & $\begin{array}{c}\text { MCHC } \\
(\%)\end{array}$ & $\begin{array}{c}\text { TPP } \\
\left(\mathrm{g} \mathrm{dL}^{-1}\right)\end{array}$ & \\
\hline Not pregnant & $7.98^{\mathrm{b}}$ & $9.28^{\mathrm{b}}$ & $25.65^{b}$ & $32.14^{\mathrm{a}}$ & $31.00^{c}$ & $5.88^{\mathrm{c}}$ & \\
\hline Initial pregnancy & $10.12^{\text {ba }}$ & $10.46^{\mathrm{a}}$ & $30.18^{\mathrm{a}}$ & $29.82^{\mathrm{ab}}$ & $41.83^{\mathrm{a}}$ & $6.65^{\mathrm{b}}$ & \\
\hline Middle pregnancy & $11.55^{\mathrm{a}}$ & $9.76^{\mathrm{b}}$ & $30.06^{\mathrm{a}}$ & $26.03^{c}$ & $43.17^{\mathrm{a}}$ & $6.68^{\mathrm{b}}$ & \\
\hline Late pregnancy & $10.67^{\mathrm{a}}$ & $10.24^{\mathrm{a}}$ & $30.18^{\mathrm{a}}$ & $28.28^{\mathrm{bc}}$ & $43.18^{\mathrm{a}}$ & $7.76^{\mathrm{a}}$ & \\
\hline Postpartum & $10.45^{\mathrm{a}}$ & $9.75^{\mathrm{b}}$ & $30.09^{a}$ & $28.79^{\mathrm{bc}}$ & $43.00^{\mathrm{a}}$ & $6.71^{\mathrm{b}}$ & \\
\hline Puerperium & $11.01^{\mathrm{a}}$ & $9.66^{\mathrm{b}}$ & $30.39^{\mathrm{a}}$ & $27.60^{\mathrm{bc}}$ & $43.01^{\mathrm{a}}$ & $6.70^{\mathrm{b}}$ & \\
\hline Weaning & $10.97^{\mathrm{a}}$ & $9.75^{\mathrm{b}}$ & $29.88^{\mathrm{a}}$ & $27.24^{\mathrm{bc}}$ & $35.04^{\mathrm{b}}$ & $6.71^{\mathrm{b}}$ & \\
\hline \multirow[t]{2}{*}{ Reference1 } & 8-18 & $8-12$ & $22-38$ & $\begin{array}{c}28-40 \\
\text { Leukogram }\end{array}$ & $30-36$ & $4-8$ & \\
\hline & $\begin{array}{l}\text { Leukocytes } \\
\left(\text { cells } \mu l^{-1}\right)\end{array}$ & $\begin{array}{l}\text { Neutrophils } \\
\left(\text { cells } \mu \mathrm{l}^{-1} \text { ) }\right.\end{array}$ & 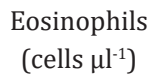 & $\begin{array}{l}\text { Monocytes } \\
\left(\text { cells } \mu l^{-1}\right)\end{array}$ & 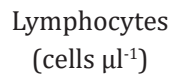 & $\begin{array}{l}\text { Basophils } \\
\left(\text { cells } \mu^{1-1} \text { ) }\right.\end{array}$ & $\begin{array}{l}\text { Neutrophils: } \\
\text { Lymphocytes }\end{array}$ \\
\hline Not pregnant & $8354^{\mathrm{a}}$ & $4875^{\mathrm{a}}$ & 403 & 228 & $2830^{\mathrm{bc}}$ & 18 & $1.7^{\mathrm{bc}}$ \\
\hline Initial pregnancy & $8724^{a}$ & $4798^{\mathrm{a}}$ & 399 & 246 & $3271^{\mathrm{b}}$ & 10 & $1.5^{\mathrm{bc}}$ \\
\hline Middle pregnancy & $8653^{\mathrm{a}}$ & $4844^{\mathrm{a}}$ & 419 & 265 & $3114^{\mathrm{b}}$ & 11 & $1.6^{\mathrm{bc}}$ \\
\hline Late pregnancy & $6840^{\mathrm{b}}$ & $4976^{a}$ & 473 & 249 & $1602^{\mathrm{d}}$ & 13 & $3.1^{\mathrm{a}}$ \\
\hline Postpartum & $7647^{\text {ba }}$ & $4813^{\mathrm{a}}$ & 488 & 219 & $2115^{c}$ & 12 & $2.3^{\mathrm{b}}$ \\
\hline Puerperium & $7787^{\text {ba }}$ & $3976^{\mathrm{b}}$ & 408 & 206 & $3187^{\mathrm{b}}$ & 10 & $1.2^{\mathrm{c}}$ \\
\hline Weaning & $8499^{\mathrm{a}}$ & $4002^{\mathrm{b}}$ & 444 & 254 & $3789^{a}$ & 10 & $1.1^{\mathrm{c}}$ \\
\hline Reference** & $4000-12000$ & $700-6000$ & $0-1000$ & $0-750$ & $2000-9000$ & $0-300$ & \\
\hline
\end{tabular}

$\overline{\mathrm{MCV}}=$ mean corpuscular volume; $\mathrm{MCHC}=$ mean corpuscular hemoglobin concentration; $\mathrm{TPP}=$ Total Plasma Protein; * Means followed by different letters differ statistically $(\mathrm{P}<0.05)$ by the Student-Newman-Keuls test; ** Intervalo reference to adult sheep (Kramer 2006). 
Table 5. Means, significance and reference values of Morada Nova sheep in all reproductive stages.

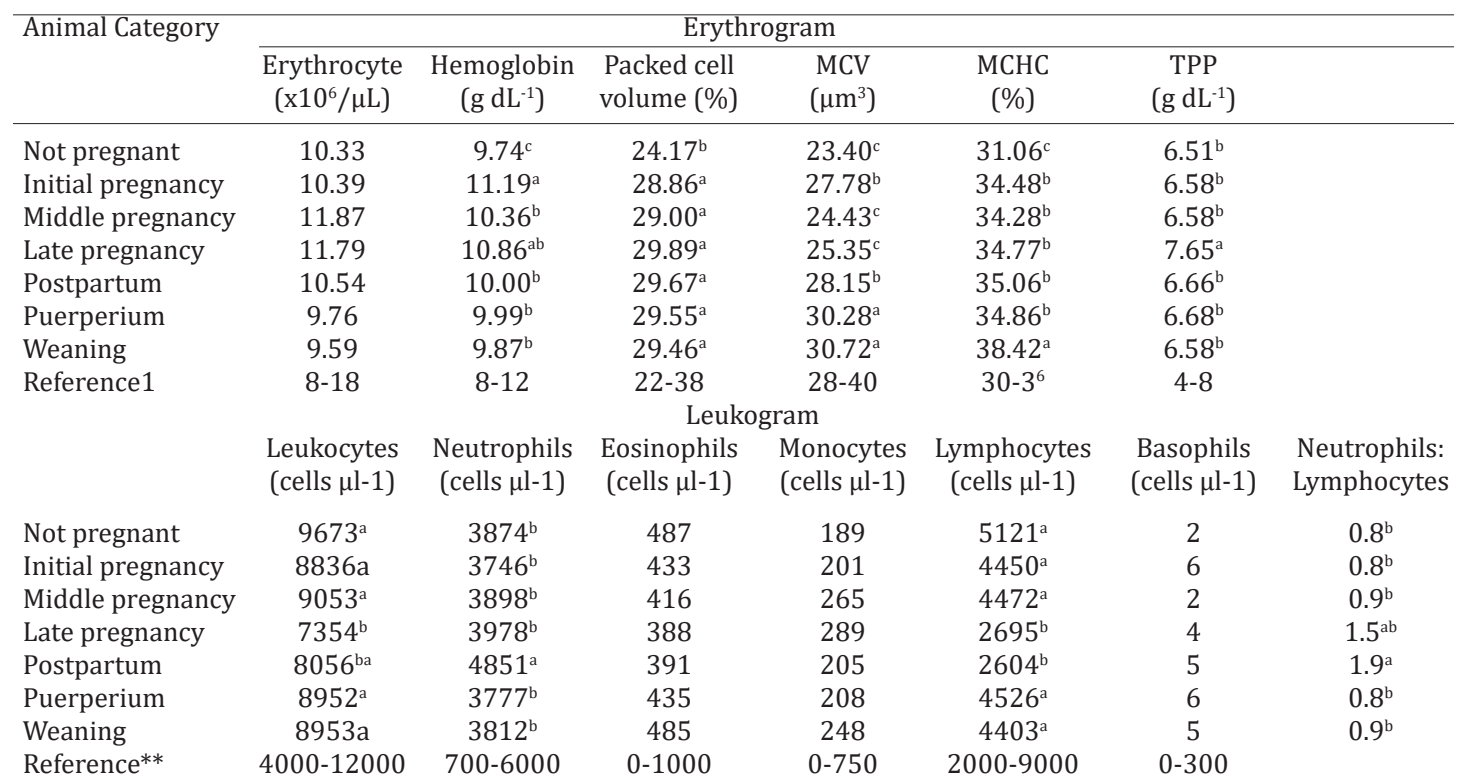

$\overline{\mathrm{MCV}}=$ mean corpuscular volume; $\mathrm{MCHC}=$ mean corpuscular hemoglobin concentration; TPP = Total Plasma Protein; * Means followed by different letters differ statistically $(\mathrm{P}<0.05)$ by the Student-Newman-Keuls test; ${ }^{* *}$ Intervalo reference to adult sheep (Kramer 2006).

tial lymphocyte counts of sheep have been reported in the literature, and there is agreement concerning the effects of factors such as breed, pregnancy and lambing (Viana et al. 2002, Adili \& Melizi 2013, Adili et al. 2013).

The results presented in Tables 4 and 5 showed that pregnancy and puerperium significantly influence the hemogram, as the number of erythrocytes, hemoglobin levels, packed cell volume percentage of the MCHC and total protein were higher $(\mathrm{P}<0.05)$ in sheep of these phases compared to sheep that were not pregnant.

The variation in the erythrocyte counts was high because prior to pregnancy, the Santa Inês sheep had $7.98 \times 10^{6}$ erythrocytes, while the average erythrocyte counts was $11.55 \times 10^{6}$ during the initial gestational stage. On the other hand, in Morada Nova ewes there was not difference in erythrocyte count (Table 5). The erythrocyte counts, in Santa Inês ewes, remained elevated $\left(10.45 \times 10^{6}\right)$ after delivery until weaning $\left(10.97 \times 10^{6}\right)$. This mechanism occurs, possibly, due to the need of supply of oxygen and nutrients in reproductive stages, as a result of fetal growth (Adili \& Melizi 2013, Adili et al. 2013). The placenta is a highly metabolically active organ, it accounts for a large fraction of the total oxygen consumed by the gravid uterus (Barry \& Anthony 2009). Bell et al. (1986) revealed that, during mid-gestation, placental oxygen consumption accounts for $80 \%$ of the total oxygen taken up by the uterus. The mean corpuscular volume (MCV) showed an inverse trend, in that this value decreased during pregnancy, puerperium and postpartum in Santa Inês breed. In addition, there was a decrease in pregnancy period until puerperium in Morada Nova breed $(\mathrm{P}<0.05)$.

Regarding the leukocyte counts, total leukocyte, neutrophil, lymphocytes counts were influenced by reproductive stages $(\mathrm{P}<0.05)$. The total number of leukocytes found in both breeds (tables 4 and 5) during late pregnancy were significantly lower than those observed in non-pregnant ewes, in ewes at the initial pregnancy stage and in ewes at the middle phase of gestation. With advancing pregnancy, the breeds had similar neutrophil count, reaching the highest values in the postpartum phase in Morada nova ewes. Concerning to neutrophil count, high values were found until postpartum in Santa Inês breed and Morada Nova breed showed higher values only in the postpartum period.

There was no influence of breed on the erythrocyte count $(\mathrm{P}=0.4718)$, mean corpuscular volume $(\mathrm{P}<0.2080)$ or total plasma protein levels ( $\mathrm{P}=0.2609)$ (Tab. 4 and 5). The Morada Nova breed showed higher levels of hemoglobin and lower packed cell volume $\left(10.29 \mathrm{~g} \mathrm{dL}^{-1}\right.$ and $28.66 \%$, respectively) than Santa Ines breed $\left(9.24 \mathrm{~g} \mathrm{dL}^{-1}\right.$ and $29.40 \%$, respectively). Regarding the leukocyte count, the total number of leukocytes $(\mathrm{P}<0.0024)$ and lymphocytes $(\mathrm{P}=0.0303)$ were different between the breeds studied.

Previous studies of red cells during pregnancy have produced conflicting results, although most have been conducted with goats and cattle, and have demonstrated a decreased number of red blood cells at birth (Earley et al. 2013, Sanni et al. 2013). However, other studies have demonstrated an increase in the number of red blood cells or hemoglobin levels, and some studies have been unable to verify differences in the erythrocyte counts, packed cell volumes and hemoglobin levels in samples taken during pregnancy compared to those taken immediately after delivery.

Physiologic anemia of pregnancy occurs during the last third of gestation, in which a decreased number of red blood cells, variation in the mean corpuscular volume and increase in the absolute values of mean corpuscular hemoglobin concentration are observed. However, this trend did not occur in this study, where a hemoconcentration as a result of 
fluid loss during farrowing could be expected. The physiologic anemia of pregnancy, or pseudo-pregnancy anemia can be avoided by administering prophylactic iron to the dam.

Early during pregnancy when a high level of fetal growth occurs, an increased metabolic rate and increased oxygen demand stimulate the release of erythropoietin by kidney tissue, resulting in an increase in the number of circulating red blood cells, hemoglobin and packed cell volume (Adili \& Melizi 2013, Shakeri et al. 2013, Yaqub et al. 2013).

The MCV decreased during the pregnancy in Santa Inês ewes indicating a decreased of red blood cells in theses reproductive stages. However, there was a recovery of this variable at the weaning. However, in an attempt to compensate this fact, the organism promoted an increase in the hemoglobin concentration by erythrocyte. Thereby, the $\mathrm{MCHC}$ values were increased with advancing pregnancy and decrease postpartum (at the moment that MCV returned to the initial level). The MCV and MCHC values obtained in this study may be related to the increase in hemoglobin. Theses hematological variables are essential vehicles for transporting the dissolved oxygen necessary for the survival of cells. This greater demand for oxygen stimulates an adaptive response in which increasing hemoglobin concentrations lead to higher levels of oxygen transport (Gravena et al. 2010).

The results of this study indicate that increased metabolic rates, possibly in response to physiological adaptations in these reproductive stages. Pregnancy and postpartum are phases of the production cycle with intense and varied changes on the metabolism and physiology of the animal. These changes on the animal physiology may affect the production, reproductive performance and animal health (Silva et al. 2013).

Despite the occasional reduction of values, the gestational parameters showed no clinical relevance and were within the reference values for sheep (Kramer 2006). Among the factors that can influence the TPP concentration are metabolic demands, hormonal balance, nutritional status and plasma acid-base balance. The increase in plasma volume was relatively greater than the increase in red blood cells with advancing gestation and led to hemodilution, with apparent decreases in hemoglobin and erythrocyte counts in late pregnancy (Okonkwo et al. 2011, Yaqub et al. 2013).

There was a decreased $(\mathrm{P}<0.05)$ on leukocytes values at the late pregnancy with increased values in the post-partum. This alteration is a characteristic of this stage, which maternal and fetal cells are reciprocally recognized by each immune system, resulting on the capacity of maintenance fetal. Therefore, the pregnancy is associated with selective tolerance, being transient and specific to alloantigens paternal (Landek-Salgado et al. 2010).

Significant differences $(\mathrm{P}=0.0301)$ among reproductive stages of sheep were detected for leutrophils:lymphocytes. The relationship between neutrophil:lymphocyte on blood can be used as physiological indicators of stress. Changes on N/L ratio are related to cortisol release (Hodgson and Rose, 1994). The difference for this marker was unfavorable to late pregnancy, postpartum and puerperium of she- $\mathrm{ep}$, as a result of the higher percentage of neutrophils compared to lower percentage of lymphocytes in theses group reproductive stages. This increase on N/L ratio indicated that ewes in the late pregnancy, postpartum and puerperium were under stress conditions compared to others stages. Some factors can be related to this condition such as fetal growth (late pregnancy), milk production (postpartum), uterine involution (puerperium) and semi-arid conditions (Sejian et al. 2014, McManus et al. 2015).

\section{CONCLUSIONS}

Pregnancy and puerperium influenced all erythrocyte indices and altered the total leukocyte count.

In terms of the influence of pregnancy and puerperium on hematological parameters, there were reestablishments of blood values such as total plasma proteins, which increase during this period to compensate for the high nutritional demands of the fetus.

The high levels of total plasma proteins remained until the end of the postpartum period when the lambs were weaned.

Acknowledgements.- To CNPq for the financial support.

\section{REFERENCES}

Adili N. \& Melizi M. 2013. The effect of age, sex and altitude on the morphometry of red blood cells in small ruminants. J. Anim. Sci. Adv. 3(1): 27-32.

Adili N., Melizi M. \& Bennoune O. 2013. The influence of age, sex and altitude on the morphometry of red blood cells in bovines. Vet. World. 6(8):476-478.

Ali A., Tharwat M. \& Al-Sobayil F.A. 2010. Hormonal, biochemical, and hematological profiles in female camels (Camelus dromedarius) affected with reproductive disorders. Anim. Reprod. Sci. 118:372-376.

Bamorovat M., Radfar M.H. \& Derakhshanfar A. 2013. A comparative evaluation of hematological, biochemical and pathological changes among infected sheep with Cysticercus tenuicollis and non-infected control group. J. Parasit. Dis. 37:1-5.

Barry J.S. \& Anthony R.V. 2009. The pregnant sheep as a model for human pregnancy. Theriogenology 69(1):55-67.

Bell A.W., Kennaugh J.M., Battaglia F.C., Makowski E.L. \& Meschia G. 1986. Metabolic and circulatory studies of fetal lamb at midgestation. Am. J. Physiol. 250:E538-E544.

Ben Salem H. 2010. Nutritional management to improve sheep and goat performances in semiarid regions. Rvta Bras. Zootec. (39):337-347.

Bezerra L.R., Ferreira A.F., Camboim E.K.A., Justiniano S.V., Machado P.C.R. \& Gomes B.B. 2008. Hematological profile of clinically healthy goats raised in Cariri. Ciênc. Agrotec. 32(3):955-960.

Bezerra L.R., Torreão J.N.C., C.A.T. Marques C.A.T., Machado L.P., Araújo M.J. \& Veiga A.M.S. 2013. Influence of concentrate supplementation and the animal category in the hemogram of Morada Nova sheep. Arq. Bras. Med. Vet. Zootec. 65(6):1738-1744.

Cetin N., Bekyurek T. \& Cetin E. 2009. Effect of sex, pregnancy and season on some haematological and biochemical blood values in Angora rabbits. Scand. J. Lab. Anim. Sci. 36(2):155-162.

Dias I.R., Viegas C.A., Silva A.M., Pereira H.F., Sousa C.P., Carvalho P.P., Cabrita A.S., Fontes P.J., Silva S.R. \& Azevedo J.M.T. 2010. Haematological and biochemical parameters in Churra-da-Terra-Quente ewes from the northeast of Portugal. Arq. Bras. Med. Vet. Zootec. 62(2):265-272.

Earley B., Drennan M. \& O'Riordan E.G. 2013. The effect of road transport in comparison to a novel environment on the physiological, metabolic and behavioural responses of bulls. Res. Vet. Sci. 95(2):811-818.

Farooq H., Samad H.A. \& Sajjad S. 2011. Normal reference Haematological 
values of one-humped camels (Camelus dromedarius) kept in Cholistan desert. J. Anim. Plant Sci. 21(2):157-160.

Gravena K., Sampaio R.C.L., Martins C.B., Dias D.P.M., Orozco C.A.G., Oliveira J.V. \& Lacerda-Neto J.C. 2010. Hematological parameters of pregnant donkey at different periods. Arq. Bras. Med. Vet. Zootec. 62(6):1514-1516.

Harewood W.J., Gillin A., Hennessys A., Armistead J., Horvath J.S. \& Tiller D.J. 2000. The effects of the menstrual cycle, pregnancy and early lactation on haematology and plasma biochemistry in the baboon (Papio hamadryas). J. Med. Primatol. 29:415-420.

Hodgson D.R. \& Rose R.J. 1994. Hematology and Biochemistry, p.63-78. In: Hodgson D.R. \& Rose R.J. (Eds), The Athletic Horse: principles and practice of equine sports medicine. W.B. Saunders, Philadelphia.

Kramer J.W. 2006. Normal hematology of cattle, sheep, and goats, p.10751084. In: Feldman B.F., Zinkl J.G. \& Jain N.C. (Eds), Schalm's Veterinary Hematology. 5th ed. Williams and Wilkins, Lippincott.

Landek-Salgado M.A., Gutenberg A., Lupi I., Kimura H., Mariotti S. \& Rose N.R. 2010. Pregnancy, postpartum autoimmune thyroiditis, and autoimmune hypophysitis: intimate relationships. Autoimmune Rev. 9(3):153-157.

McManus C., Bianchini E., Paim T.P., Lima .G., Braccini Neto J., Castanheira M., Esteves G.I.F., Cardoso C.C. \& Dalcin V.C. 2015. Infrared thermography to evaluate heat tolerance in different genetic groups of lambs. Sensors 15(1):17258-17273.

Minka N.S. \& Ayo J.O. 2007. Physiological responses of transported goats treated with ascorbic acid during hot dry season. Anim. Sci. J. 78(2):164172.

NRC 2007. Nutrient Requirements of Small Ruminants: sheep, goats, cervids and New World camelids. Natl Acad. Press, Washington, DC. 384p.

Okonkwo J.C., Omeje J.S. \& Okonkwo I.F. 2011. Effect of source and sex on blood protein fractions of West African dwarf goats (WADG). Res. Opin. Anim. Vet. Sci. 1(3):158-161.

Oladele S.B., Ayo J.O., Ogundipe S.O. \& Esievo K.A.N. 2005. Seasonal and sex variations in packed cell volume, haemoglobin and total protein of the guinea fowl (Numida meleagris) in Zaria, Northern Guinea Savannah zone of Nigeria. J. Trop. Biosci. 5(2):67-71.
Oliveira A.C.O., Ribeiro Filho J.D., Guimarães J.D., Silva A.R., Dantas W.M.F., Bonfá L.P. \& Farias S.K. 2010. Concentration of anticoagulant, time and temperature of storage on the haematological parameters in automated blood count. Ciência Rural 40(12):2521-2526.

Papaioannou N., Giadinis N.D. \& Tsaousi P. 2013. Concurrent scrapie and chronic coenurosis in two Chios sheep. Slov. Vet. Res. 50(1):35-40.

Sanni T.M., Onasanya G.O., Adefenwa M.A., Yakubu A., Ikeobi C.O.N., Adebambo O.A., Talabi A.O., Ozoje M.O., Wheto M., Takeet M.I., Peters S.O., Donato M., Thomas B.N. \& Imumorin I.G. 2013. Molecular diagnosis of subclinical African Trypanosoma vivax infection and association with physiological indices and serum metabolites in extensively managed goats in the tropics. Open J. Vet. Med. 3:39-45.

Sejian V., Bahadur S. \& Naqvi S.M.K. 2014. Effect of nutritional restriction on growth, adaptation physiology and estrous responses in Malpura ewes. Anim. Biol. 64(2):189-205.

Shakeri P., Riasi A., Alikhani M., Fazaeli H. \& Ghorbani G.R. 2013. Effects of feeding pistachio by-products silage on growth performance, serum metabolites and urine characteristics in Holstein male calves. J. Anim. Physiol. Anim. Nutr. 7(6):1022-1029.

Silva T.P.D., Marques C.A.T., Torreão J.N.C., Araújo M.J., Bezerra L.R. \& Pereira A.M. 2013. Adaptações fisiológicas no período de transição em ruminantes domésticos. Med. Vet. 7(2):32-44.

Stanger K.J., Ketheesan A.J. \& Parker C.J. 2005. The effect of transportation on the immune status of Bos indicus steers. J. Anim. Sci. 8:2632-2636.

Tibbo M., Woldemeskel M., Argaw K. \& Rege J.E.O. 2008. Serum enzyme levels and influencing factors in three indigenous Ethiopian sheep breeds. Comp. Clin. Pathol. 17(3):149-155.

Viana R.B., Birgel Junior E.H., Ayres M.C.C., Biojoni F.S.M., Souza M.C.C. \& Birgel E.H. 2002. Influence of pregnancy and puerperium in the leucogram of Saanen goats (Capra hircus), bred in the state of São Paulo. Revta Bras. Zootec. 39(4):196-201.

Yaqub L.S., Kawu M.U. \& Ayo J.O. 2013. Influence of reproductive cycle, sex, age and season on haematologic parameters in domestic animals: a review. J. Cell Anim. Biol. 7(4):37-43. 